\author{
Jurnal E-KOMTEK (Elektro-Komputer-Teknik) \\ Vol. 4, No. 2 (2020) pp. 145-154 \\ https://jurnal.politeknik-kebumen.ac.id/index.php/E-KOMTEK \\ p-ISSN : 2580-3719 e-ISSN : 2622-3066
}

\title{
Penggunaan Media Belajar Pembangkit Tegangan Gelombang Sinus Berbasis XR2206 Tahan Hubung Singkat Dalam Peningkatan Kompetensi Siswa SMK N 1 Pundong Yogyakarta
}

\author{
Yulia Bherlinda \\ Diploma Teknik Elektronika, Politeknik Dharma Patria, Indonesia, 55431 \\ E-mail : bherlinda0919@gmail.com \\ Doi $\quad$ : https://doi.org/10.37339/e-komtek.v4i2.390
}

Diterbitkan oleh Politeknik Dharma Patria Kebumen
Info Artikel
Diterima :
28-11-2020
Diperbaiki :
13-12-2020
Disetujui :
13-12-2020

\begin{abstract}
ABSTRAK
Penelitian ini bertujuan untuk: (1) mengetahui pencapaian kompetensi siswa yang mengikuti pembelajaran menggunakan media belajar pembangkit tegangan gelombang sinus berbasis XR2206 tahan hubung singkat dengan siswa yang mengikuti pembelajaran metode konvensional, (2) mengetahui perbedaan aspek kognitif, aspek afektif, aspek psikomotorik siswa yang mengikuti pembelajaran menggunakan media belajar pembangkit tegangan gelombang sinus berbasis XR2206 tahan hubung singkat dengan siswa yang mengikuti pembelajaran metode konvensional pada mata diklat Alat Ukur Listrik di SMK N 1 Pundong. Penelitian ini merupakan penelitian eksperimen dengan desain penelitian kuasi tipe Randomized Control-Group Pretest-Posttest Design. Hasil penelitian menunjukan bahwa: (1) metode pembelajaran dengan media belajar pembangkit tegangan gelombang sinus berbasis XR2206 tahan hubung singkat lebih efektif dengan selisih nilai pre-post test 24,03 , sedangkan dengan metode konvensional memiliki selisih nilai pre-post test 16,26, (2) ada perbedaan yang signifikan dari hasil belajar antara kelas yang menggunakan media belajar pembangkit tegangan gelombang sinus berbasis XR2206 tahan hubung singkat dengan metode konvensional, dengan nilai t hitung aspek kognitif, afektif dan psikomotorik masing-masing yaitu sebesar $(-2,030),(-2,431)$, dan $(-2,352)$.

Kata kunci: Hasil Belajar; Media Belajar; Pembangkit Tegangan; XR2206
\end{abstract}

\begin{abstract}
This study aims to: (1) determine the competence attainment of students who take learning using the XR2206-based sine wave voltage generator learning media with short circuit resistance with students who take conventional methods of learning, (2) knowing the differences in cognitive aspects, affective aspects, and psychomotor aspects of students who following the learning using the XR2206based sine wave voltage generator learning media with short circuit resistance with students who took the conventional method learning in the Electrical Measuring Instrument training course at SMK N 1 Pundong. This research is an experimental study with a quasi-type randomized controlgroup pretest-posttest design. The results showed that: (1) the learning method using the XR2206based sine wave voltage generator learning media was more effective with a pre-post test score difference of 24.03, while the conventional method had a pre-post test difference of 16.26, (2) there is a significant difference in learning outcomes between classes using the XR2206-based sine wave voltage generator learning media with a conventional method, with the tvalue of cognitive, affective and psychomotor aspects, respectively (-2.030). -2,431), and (-2,352).

Keywords: Learning outcomes; Learning Media; Voltage Generator; XR2206
\end{abstract}

Alamat Korespondensi $\quad$ : Jl. Letnan Jenderal Suprapto No.73 Kebumen, Jawa Tengah, Indonesia 55431 This work is licensed under a Creative Commons Attribution-NonCommercial 4.0 International License. 


\section{PENDAHULUAN}

Kebutuhan masyarakat dimasa teknologi yang semakin berkembang saat ini, pendidikan yang berkualitas semakin berkurang. Siswa dapat dibimbing dan diarahkan untuk mampu belajar secara mandiri individu maupun kelompok sebagai upaya dan strategi dalam memaksimalkan hasil pencapaian belajar. Menyisipkan media belajar dan mengkombinasikan yang dilakukan guru atau pendidik merupakan salah satu strategi yang dapat diterapkan, khususnya di sekolah.

Suatu pembelajaran dapat dikatakan efektif apabila segi sarana penunjang dan prosesnya berpengaruh pada segi prestasi siswa berdasarkan referensi [1]. Dari hasil pra survey yang melibatkan siswa, guru, dan peneliti, ditemukan bahwa siswa di SMK N 1 Pundong cenderung merasa bosan, kurang aktif dan kurang antusias dalam mengikuti pelajaran. Dari hasil survey tersebut, peneliti ingin menggunakan metode baru dan nyata dalam pembelajaran sehingga siswa dapat aktif dan antusias. Metode yang dapat disesuaikan dengan kondisi di lapangan salah satunya adalah dengan menggunakaan media belajar modul pembangkit tegangan gelombang sinus berbasis XR2206 tahan hubung singkat sebagai media pembelajaran.

Pendidik, siswa atau peserta didik, materi pembelajaran, metode balajar, evaluasi hasil serta media yang digunakan merupakan komponen-komponen pembelajaran [2]. Proses pembelajaran dari suatu induvidu atau kelompok siswa akan dinilai oleh guru atau pendidik sebagai tujuan mengetahui keberhasilan suati proses belajar. Tiga ranah yaitu aspek kognitif, afektif, dan psikomotorik merupakan pertimbangan dasar dalam suatu penentuan penilaian hasil pembelajaran. Menurut Benny Pribadi [3] pada dasarnya aktivitas belajar pada peserta didik diciptakan untuk memunculkan suatu proses pembelajaran.

Proses pembelajaran yang konvensional sering ditemukan dibanyak sekolah dan SMK N 1 Pundong merupakan salah satunya. Siswa yang kurang motivasi, kurang minat terhadap proses belajar, kurang antusias menjadi salah satu penyebab dari penggunaan metode yang konvensional, sehingga siswa menjadi cepat merasa bosan [4]. Salah satu upaya yang dapat dilakukan agar siswa menjadi lebih aktif dan antusias adalah dengan menggunakan media belajar sebagai sarana penunjang keberhasilan proses pembelajaran. Salah satu metode belajar yang efektif memberikan suatu kasus dan siswa mencari literatur dan solusi secara mandiri sehingga siswa lebih aktif dan memberikan feedback kepada guru pada referensi [5]. 
Menurut Azhar Arsyad [6], komponen yang dapat menjadi sumber belajar dan mengandung materi bersifat instruksional serta dapat menggugah minat siswa adalah sebuah media, karena proses dan sarana prasarana merupakan komponen penunjang keberhasilan dan keefektifan pembelajaran. Menurut Endang Mulyatiningsih peserta didik harus dilatih untuk mampu berpikir kreatif dalam menghadapi suatu problem baik individu maupun secara berkelompok [7]. Media pembelajaran ini merupakan pembangkit gelombang sinus melalui modifikasi yang menggunakan komponen pasaran dengan berkualitas baik serta mudah diperbaiki apabila terjadi kerusakan secara tiba-tiba. Metode pembelajaran dengan penggunaan media belajar pembangkit tegangan gelombang sinus berbasis XR2206 tahan hubung singkat diharapakan dapat menambah pencapaian hasil belajar siswa program keahlian Teknik Audio Video pada mata diklat Alat Ukur Listrik di SMK N 1 Pundong.s.

\section{MATERIAL DAN METODE}

Desain penelitian yang digunakan adalah quasi exsperiment tipe Randomized Control-Group Pretest-Posttest Design. Penelitian dilakukan pada kelas X TAV A dan TAV B Teknik Audio Video di SMK N 1 Pundong. Populasi siswanya adalah 62 siswa. Kelas kontrol dengan metode konvensional ada 31 siswa, sedangkan kelas eksperimen ada 31 siswa yang menggunakan media pembangkit tegangan gelombang sinus berbasis XR2206 tahan hubung singkat. Teknik pengambilan data dengan tes untuk aspek kognitif, angket untuk afektif, dan observasi untuk psikomotorik. Teknik analisis data yang diterapkan adalah dengan teknik analisis deskriptif dan uji-t.

\section{HASIL DAN PEMBAHASAN}

Sampel yang diambil untuk penelitian ini merupakan kelas di Jurusan Kelistrikan sebuah sekolah menegah kejuruan di Kebupaten Bantul, yaitu SMKN 1 Pundong Bantul. Terdapat 2 kelas program keahlian Teknik Audio Video SMK N 1 Pundong, yaitu kelas TAV A dan kelas TAV B. Jumlah siswa setiap kelas ada 31 siswa dengan rincian TAV A adalah kelas kontrol dan TAV B adalah kelas eksperimen. Pemilihan dilakukan secara acak atau random untuk memilih kelas kontrol dan eksperimen. Kelas kontrol akan diberikan pembelajaran seperti biasa yang bersifat konvensional, sedangkan kelas eksperimen dengan media pembangkit tegangan gelombang sinus berbasis XR2206 tahan hubung singkat. 
Pembangkit gelombang yang digunakan adalah XR2206 dari EXAR Corporation dengan modifikasi penguat daya yang diambil dari audio 50 watt SP 100D NAS (new audio sistem) yang dicatu \pm 32 volt diubah menjadi berdaya rendah dengan tegangan catu \pm 12 volt. Gelombang bentuk sinusoidal, gergaji, ataupun kotak merupakan gelombang yang dihasilkan rangakain isolator. Frekuensi dikenal sebagai suatu arus bolak-balik yang menyelesaikan jumlah siklus per detik (cycle per second) [8]. Gambar 1 berikut merupakan gambar rangkaian modul media pembangkit tegangan gelombang sinus berbasis XR2206 tahan hubung singkat. Rangkaian media belajar disajikan pada Gambar 1.
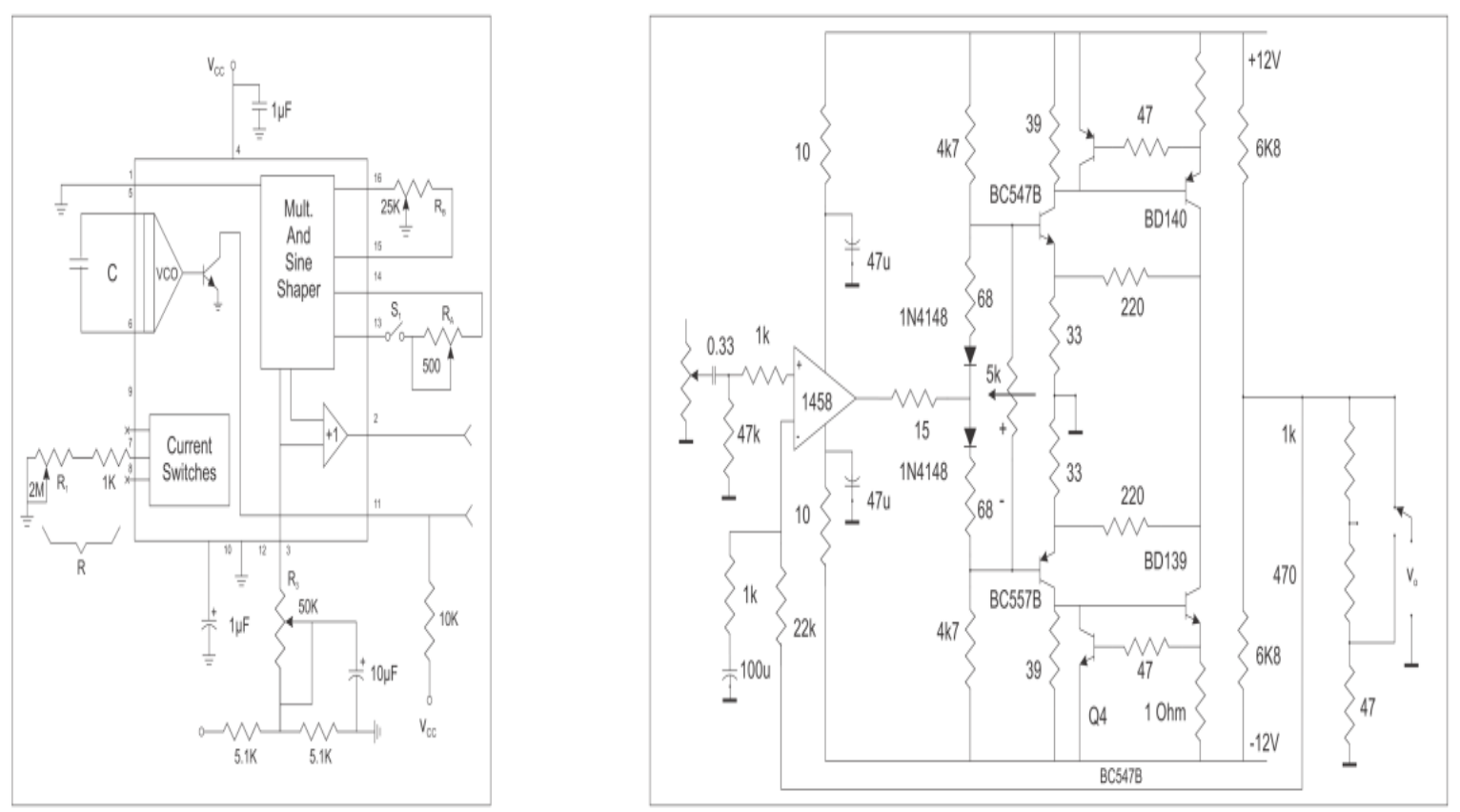

\section{Gambar 1. Rangkaian Media Belajar}

Terdapat tiga aspek yang dinilai yaitu kognitif, afektif, dan psikomotorik dengan masingmasing indikator penilaian pencapaian kompetensi berdasarkan referensi [9]. Pengukuran dengan tes soal pilihan ganda berjumlah 17 soal dilakukan untuk menilai aspek kognitif, 24 soal dalam bentuk angket untuk afektif, dan 16 soal berbentuk pernyataan pengamatan para siswa untuk psikomotorik yang dilakukan oleh dua orang observer. Pada soal pilihan ganda diberikan nilai 0 untuk jawaban salah, dan nilai 1 untuk jawaban benar. Angket untuk menilai aspek afektif siswa menggunakan skala linkert dengan rentang nilai 1-4, sedangkan data aktivitas siswa bernilai 0 untuk "tidak" dan 1 untuk "ya". Tabel 1 berikut merupakan hasil pretest untuk kelas kontrol dan kelas eksperimen. 
Tabel 1. Hasil Pretest

\begin{tabular}{lrc}
\hline \multirow{2}{*}{ Nilai Perhitungan } & \multicolumn{2}{c}{ Skor pretest } \\
& Kelas Kontrol & Kelas Eksperimen \\
\hline Skor Tertinggi & 88,00 & 88,00 \\
Skor Terendah & 23,00 & 23,00 \\
Mean & 54,4194 & 56,2903 \\
Median & 58,0000 & 58,0000 \\
Std. Deviasi & 21,6345 & 20,4991 \\
\hline
\end{tabular}

Setelah kedua kelas dilakukan pratest, kemudian kelas eksperimen diberikan treatment yaitu menggunakan media pembelajaran pembangkit tegangan gelombang sinus berbasis XR2206 tahan hubung singkat. Setelah itu kedua kelas dilakukan posttest untuk mengetahui sejauh mana perbedaan yang dihasilkan. Berikut merupakan hasil dari posttest kedua kelas yang dijabarkan pada Tabel 2.

Tabel 2. Hasil Posttest

\begin{tabular}{lcc}
\hline Nilai Perhitungan & \multicolumn{2}{c}{ Skor Posttest } \\
& Kelas Kontrol & 100,00 \\
\hline Skor Tertinggi & 100,00 & 47,00 \\
Skor Terendah & 35,00 & 80,3226 \\
Mean & 70,6774 & 82,0000 \\
Median & 70,0000 & 17,6850 \\
Std. Deviasi & 18,0451 & \\
\hline
\end{tabular}

Penilaian untuk segi afektif diberikan angket kepada siswa yang berisi 24 pertanyaan. Kemudian perhitungan posttest angket siswa antara kelas kontrol dengan pembelajaran konvensional dan kelas eksperimen yang diberikan media pembelajaran pembangkit tegangan gelombang sinus berbasis XR2206 tahan hubung singkat dapat dilihat pada Tabel 3.

Tabel 3. Hasil Posttest Angket Siswa

\begin{tabular}{lll}
\hline Nilai Perhitungan & $\begin{array}{l}\text { Skor Posttest } \\
\text { Kelas Kontrol }\end{array}$ & Kelas Eksperimen \\
\hline Skor Tertinggi & 91,00 & 90,00 \\
Skor Terendah & 61,00 & 66,00 \\
Mean & 74,3548 & 78,2581 \\
Median & 73,0000 & 78,0000 \\
Std. Deviasi & 6,94045 & 5,63304 \\
\hline
\end{tabular}


Kemudian, dari segi psikomotorik diberikan lembar pengamatan oleh dua orang observer saat pembelajaran diberlangsungkan. Dua observer tersebut merupakan guru Teknik Audio Video dengan penyataan berupa checklist jawaban "ya" yang bernilai 1 dan "tidak" yang bernilai 0 . Hasil analisis pengamatan terdapat pada Tabel 4.

Tabel 4. Hasil Penilaian Lembar Pengamatan Siswa

\begin{tabular}{|c|c|c|c|c|}
\hline \multirow{2}{*}{ Nilai Perhitungan } & \multicolumn{4}{|c|}{ Skor } \\
\hline & \multicolumn{2}{|l|}{ las Kontrol } & \multicolumn{2}{|c|}{ Kelas Eksperimen } \\
\hline Skor Tertinggi & \multicolumn{2}{|l|}{16,00} & \multicolumn{2}{|c|}{16,00} \\
\hline Skor Terendah & \multicolumn{2}{|l|}{3,00} & \multicolumn{2}{|c|}{4,00} \\
\hline Mean & \multicolumn{2}{|l|}{10,1613} & \multicolumn{2}{|c|}{12,4516} \\
\hline Median & \multicolumn{2}{|l|}{11,0000} & \multicolumn{2}{|c|}{14,0000} \\
\hline Std. Deviasi & \multicolumn{2}{|l|}{3,59719} & \multicolumn{2}{|c|}{4,05659} \\
\hline \multirow{3}{*}{\multicolumn{5}{|c|}{$\begin{array}{l}\text { Uji prasyarat yang dilakukar } \\
\text { njukkan kenormalan data dan me } \\
\text { digunakan adalah data dari kelas } \\
\text { t siswa, dan lembar pengamatan } \\
\text { litas dapat dilihat pada Tabel } 5 \text {. }\end{array}$}} \\
\hline & & & & \\
\hline & & & & \\
\hline & D Absolute & & & \\
\hline Normalitas & (Dhitung) & D tabel & Sig. & Keterangan \\
\hline retest kelas kontrol & 0,152 & 0,238 & 0,473 & Normal \\
\hline retest kelas eksperimen & 0,141 & 0,238 & 0,570 & Normal \\
\hline osttest kelas kontrol & 0,126 & 0,238 & 0,712 & Normal \\
\hline osttest kelas eksperimen & 0,157 & 0,238 & 0,426 & Normal \\
\hline ngket siswa kelas kontrol & 0,104 & 0,238 & 0,891 & Normal \\
\hline ngket siswa kelas eksperimen & 0,102 & 0,238 & 0,906 & Normal \\
\hline ktivitas siswa kelas kontrol & 0,192 & 0,238 & 0,204 & Normal \\
\hline ktivitas siswa kelas eksperimen & 0,219 & 0,238 & 0,102 & Normal \\
\hline
\end{tabular}


Data dikatakan berdistribusi normal apabila Dhitung (D Absolute) $<$ Dtabel dengan taraf Signifikansi $(p)>0,05(5 \%)$. Hasil diatas menunjukkan bahwa data nilai pretest, posttest, angket siswa, dan aktivitas siswa berdistribusi normal. Kemudian untuk hasil uji homogenitas digunakan uji levene untuk mengetahui homogenitas varian. Data dikatakan homogen apabila nilai signifikansi lebih besar daripada $5 \%(0,05)$. Ho diterima dan Ha ditolak apabila nilai signifikansi lebih dari 0,05, dan sebaliknya. Uji homogenitas dilakukan pada nilai pretest, posttest, angket, dan aktivitas siswa kedua kelas. Hasil uji homogenitas dapat dilihat pada Tabel 6.

Tabel 6. Uji Homogenitas

\begin{tabular}{llll}
\hline Uji Homogenitas & $\begin{array}{l}\text { Levene } \\
\text { Statistic }\end{array}$ & Sig. & Keterangan \\
\hline Pretest siswa & 0,426 & 0,516 & Homogen \\
Posttest siswa & 0,047 & 0,829 & Homogen \\
Angket siswa & 0,933 & 0,338 & Homogen \\
Aktivitas siswa & 1,346 & 0,251 & Homogen \\
\hline
\end{tabular}

Berdasarkan hasil uji homogenitas pada Tabel 6 diketahui nilai signifikasi pretest, posttest, angket siswa, dan aktivitas siswa $>0,05$. Ho diterima apabila nilai sig. lebih besar dari 0,05, sehingga disimpulkan bahwa kedua varian tersebut homogen. Hasil nilai levene, semakin kecil nilainya, maka nilai homogenitasnya semakin tinggi. Setelah dilakukan uji prasyaratan, maka langkah berikutnya adalah dengan uji hipotesis. Kelas kontrol dan kelas eksperimen akan dibandingkan dengan pengujian hipotesis. Sebelumnya diketahui bahwa data berdistribusi normal dan bersifat homogen dari hasil uji normalitas dan uji homogenitas data pretest dan posttest. Sehingga uji parametrik dengan teknik uji-t digunakan dalam uji hipotesis peneitian ini.

Hipotesis Ho akan diterima apabila $-\mathrm{t}_{\text {tabel }} \leq \mathrm{t}_{\text {hitung }} \leq \mathrm{t}_{\text {tabel }}$, sedangkan batas penerimaan Ha adalah apabila thitung berada di luar penerimaan Ho dengan uji-t taraf sig. 0,05. Uji-t dengan Independent $t$-Test didapatkan hasil thitung yaitu -0,354 dan tabel yaitu 2,000. Thitung diketahui berada dalam interval $-\mathrm{t}_{\text {tabel }} \leq$ thitung $\leq$ tabel sehingga Ho diterima dan kesimpulan yang diambil adalah tidak terdapat perbedaan signifikan pada hasil pretest kedua kelas.

Uji berikutnya adalah uji hasil pre-posttest kelas non-eksperimen (kontrol) dengan tujuan mengetahui ada tidaknya perbedaan yang signifikan. Pengujian dilakukan dengan uji-t Paired Samples T-Test dan diketahui hasil thitung sebesar -5,212 serta taraf signifikasinya sebesar 2,042. Perhitungan menunjukkan bahwa thitung < tabel sehingga Ha diterima dan disimpulkan bahwa nilai pre-postest kelas kontrol berbeda secara signifikan. Uji-t Paired Samples T-Test selanjutnya 
juga digunakan untuk menguji nilai pretest-posttest kelas eksperimen dengan tujuan mengetahui signifikansi perbedaannya. Hasil perhitungan diperoleh thitung sebesar $-4,449$, taraf signifikansi yaitu 2,042. Diperoleh thitung $<$ tabel sehingga Ha diterima yaitu pretest postest kelas eksperimen berbeda secara signifikan.

Nilai posttest aspek kognitif kedua kelas yaitu kelas kontrol dan eksperimen diuji dengan uji-t Independent Samples T Test dalam rangka mengetahui adakah perbedaan secara signifikan. Hasil diketahui thitung sebesar -2,030 taraf signifikansi yaitu 2,000, sehingga Ha diterima karena thitung $<$ tabel. Dapat disimpulkan bahwa ada perbedaan secara signifikan aspek kognitif dari posttest antara kedua kelas tersebut. Kemudian juga dilakuan pengujian dari aspek afektif yang diuji dengan teknik uji-t yang sama dengan aspek kognitif. Perhitungan diperoleh thitung yaitu 2,431 taraf signifikansinya 2,000 lebih rendah dari tabel sehingga Ha diterima yaitu ada perbedaan secara signifikan aspek afektif dari kedua kelas. Uji terakhir adalah pengujian aspek psikomotorik diperoleh thitung -2,352 taraf signifikansi 2,000 dan Ha diterima yang dapat diambil kesimpulan bahwa ada perbedaan antara kelas yang menggunakan media belajar dengan kelas konvensional.

Dokumentasi dari pembelajaran menggunakan media belajar pembangkit tegangan gelombang sinus berbasis XR2206 tahan hubung singkat. Gambar gelombang singkat disajikan pada Gambar 2.

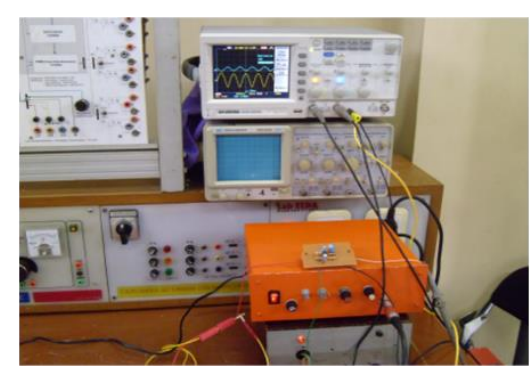

Gambar 2. Gelombang Sinus

Proses pembelajaran disajikan pada Gambar 3.

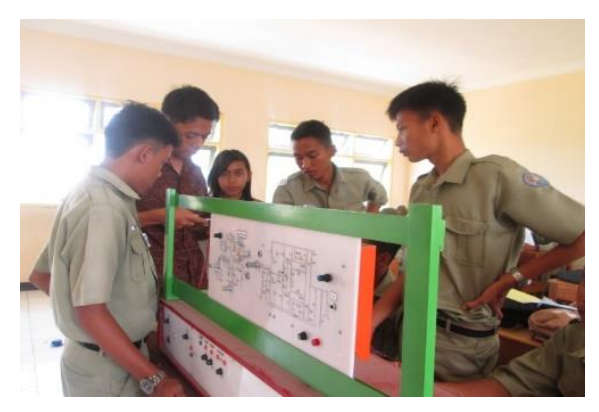

Gambar 3. Proses Pembelajaran 
Aktivitas siswa dengan media pembelajaran disajikan pada Gambar 4.

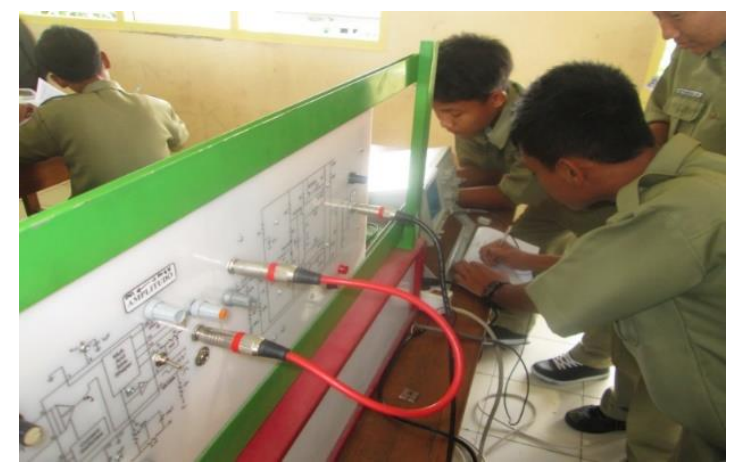

Gambar 4. Aktivitas Siswa dengan Media Belajar

\section{KESIMPULAN}

Kesimpulan dari hasil pengujian adalah: 1) mean pretest kelas eksperimen dan kontrol yaitu 56,29 dan 54,42. Kemudian, posttest kelas eksperimen dan kontrol yaitu 80,32 dan 70,68. Selisih mean pretest-posttest kelas eksperimen dengan media pembelajaran pembangkit tegangan gelombang sinus berbasis XR2206 tahan hubung singkat yaitu 24,03, sedangkan kelas kontrol yaitu 16,26. Kelas eksperimen dengan media lebih tinggi peningkatan nilainya dibandingkan dengan kelas kontrol dilihat dari hasil tersebut. 2) mean posttest kelas eksperimen dengan media belajar pembangkit tegangan gelombang sinus berbasis XR2206 tahan hubung singkat memiliki rerata 80,32, sedangkan kelas kontrol sebesar 70,68. Kemudian mean aspek afektif kelas eksperimen yaitu 78,26, sedangkan kelas kontrol yaitu 74,35. Terakhir yaitu pada aspek psikomotorik mean kelas eksperimen sebesar 12,45, sedangkan kelas kontrol sebesar 10,16. 3) hasil ketiga perhitungan disimpulkan ada perbedaan secara signifikan dari segi kognitif, afektif, maupun psikomotorik antara kelas eksperimen dan kelas kontrol. Jadi, penggunaan media belajar pembangkit tegangan gelombang sinus berbasis XR2206 tahan hubung singkat lebih efektif dibandingkan dengan penggunaan metode belajar konvensional.

\section{REFERENSI}

[1] O. Hamalik, Proses Belajar Mengajar, Jakarta: Bumi Aksara, 2001.

[2] Dimyati and Mujiono, Belajar dan Pembelajaran, Jakarta: Rineke Cipta, 2006.

[3] B. A, Model Desain Sistem Pembelajaran, Jakarta: PT Dian Rakyat, 2009.

[4] K. Tooping, The Peer Tutoring Handbook: Promoting Co-Operative Learning, Cambridge: Brookline Books, 1988. 
[5] A. Woolfolk, Educational Phychology Active Learning Edition, Yogyakarta: Pustaka Pelajar, 2009.

[6] A. Arsyad, Media Pembelajaran, Jakarta: Rajawali Press, 2011.

[7] E. Mulyatiningsih, Riset Terapan : Bidang Pendidikan dan Teknik, Yogyakarta: UNY Press, 2011.

[8] S. R. L, Electronic Communication, Jakarta: Erlangga, 1991.

[9] Z. Arifin, Evaluasi Pembelajaran, Bandung: Remaja Rosdakarya, 2009.

[10] Supardi, Aplikasi Statistika dalam Penelitian: Konsep Statistika yang Lebih Komperensif, Jakarta: Change Publication, 2013. 